\title{
A Brief Overview of Medieval Persian Literature
}

\author{
Bahman Solati $^{1^{*}}$ \\ ${ }^{1}$ University of California, Berkeley, USA \\ *Bahman Solati, E-mail: bahmansolati@ berkeley.edu
}

Received: July 14, 2017

Accepted: July 20, 2017

Online Published: July 24, 2017

doi:10.22158/selt.v5n3p496

URL: http://dx.doi.org/10.22158/selt.v5n3p496

\begin{abstract}
Reviewing the origins of a particular literary history allows us to better comprehend the allusions the literature conveys and why we appreciate them. It also allows us to anticipate how the literature may progress (Fouchecour, 2006) I will try to keep this approach in the reader's mind in presenting this brief summary of medieval Persian literature, a daunting task considering the multiplicity and wealth of the texts and documentation on the subject (Fouchecour, 2006). In this study we will pay special attention to the progress of Persian literature over the last millennia, concentrating in particular on the early development and background of various literary genres in Persian. Although the idea of literary genres is rather subjective and unstable (Perkins, 1993, pp. 29-33), studying them is a worthwhile approach for an overview, enabling better understanding, deeper argumentation, and deeper analysis than would a simple listing of dates, titles, and basic biographical facts of the giants of Persian literature.
\end{abstract}

\section{Keywords}

literature, Persian literature, classical poetry, language and culture

\section{Introduction}

The transition and change that have taken place over time, or the outlining of literary development through continuous generations and eras, are essential to literary examination. Flourishing Persian literature, unquestionably molded by historic events, lends itself to this approach: one can observe vast differences between the Persian literature of the tenth century and that of the eleventh or the twelfth, and so on (Fouchecour, 2006). The fourteenth century stands as a bridge between the previous and the later periods, the Mongol and Timūrīd, followed by the Safavids in Persia and the Mughals in India. Given the importance of local courts and their support of poets and writers, it is quite understandable that literature would be significantly influenced by schools of thought in different provinces of the Persian world (Șafā, 1380/2001). In this essay, I use the word literature to refer to the written word adeptly and artistically created. One of the striking characteristics of Old Persian literature is its integration of well-shaped and well-expressed writings by historians and mystical figures (Fitzherbert, 
1996). The history of the Mongols by 'Ațā-Malik Juvainī (d. 685/1283), for instance, is not only the reliable work of a great historian but also the creation of a prominent man of letters who skillfully contrasts his fine prose with carefully selected lines of medieval poets, and most particularly of Firdawsī, to support his own historical annotations and inscribe the dramatic events of his lifetime against the backdrop of the cosmic events of Iranian traditional history (Fouchecour 2006). A different and earlier example, from the eleventh century, is the well-known Tārikh-i Mas'udī by Abu'l-Faḍl Muḥammad Ḥusayn Bayhaqī (d. 470/1068) (Dihkhudā, Lughat-nāma, 1373/1994). This text—all that survives from what was originally a general, thirty-volume history-reports the events of the reign of the second Ghaznavid ruler, while also occasionally surveying the rule of previous sovereigns. The writer maintains a careful balance in his reading of events and deployment of historical moments, revealing himself to be both a caring witness and a talented artist (Dihkhudā, Lughat-nāma, 1373/1994).

In referring to the consecutive span of classical Persian literature, I mean here the aesthetic and cultural concerns expressed in Persian between the ninth century, with the advent of papermaking in Samarqand, and the mid-nineteenth century, when the first printing presses went into operation in Tabriz. Both papermaking and the printing press had a radical impact on the literary milieu and redefined the relationship between narrators and their audience, and writers and readers (Chaytor, 1945). The classical period was a favorable time for princely patronage, and the royal courts were often receptive to the arrival of great spiritual figures and free thinkers. A man of great literary skill in this period was expected to be familiar with the arts and sciences of his time. In the twelfth century, for instance, Khāqānī—who, with Anvarī, according to Jan Rypka, brought the panegyric ode (qașida) to its height (Rypka, 1968) — was a great poeta doctus (poet scholar) (Beelaert, 1996), respected as both hakim (sage) and shāe ir (poet).

\section{The Persian Language between Arabic and Turkish}

Modern Persian, a derivative of Old Persian (Lazard, 1983, p. 382), "belongs to the Indo-Iranian branch of the Indo-European languages" (Fouchecour, 2006). This ancestry makes its grammar and vocabulary similar to those of Kurdish and Pashto. Persian also includes many loanwords from Arabic. The script is modified from Arabic, and like Arabic it has a highly developed calligraphy, a leading Islamic art form. This script is just as vital to the structure of the poetry, and it is thoroughly blended with Persian prosody and poetic metaphors (Schimmel, 1992). The Persians also absorbed Muslim culture through Arabic. Their most distinguished scholars and the clerical classes at court were skilled in both languages. Bilingualism among leading cultural figures was a noteworthy feature of the time (Rypka, 1968).

Far from bringing to an end the use of the Persian language, both spoken and written, in Persia or elsewhere, the Arab invasion of Iran in the seventh century merely heralded a process of evolution (Lazard, 1983, p. 382). In this process Middle Persian, the language of the Sassanid court (c. 
225-651/823-1249), evolved into Persian, which became the language of early literary landmarks such as Firdawsī’s Shāh-nāma and Bal'amī’s translation and adaptation of Țabarī's History, and which in turn developed into Modern Persian.

If the Persians played more than just a passive role in Arabic literature, and even in the greater formulation of Islamic traditional culture, this is in great measure because the entire extent, and not merely a part, of the ancient Sāsāniān Empire, with all of its institutions and cultural traditions, fell to the lot of the Arab conquerors. They conquered the Persians but did not do away with the age-old cultural institutions of that people; on the contrary, the Arabs were in their turn conquered, culturally speaking, by the Persians (Danner, 1986).

The Middle Persian language itself survived among populations of Zoroastrians in Persia in the first three centuries after the rise of Islam, and substantial religious texts in Middle Persian survive from this period. But classical Persian poetry relies heavily on tradition and cultural memory, displaying strong connections with the pre-Islamic past in aspects including its meter (attuned to Arabic), its lexis, and major themes (Elwell-Sutton, 1986).

Through a diachronic study of classical Persian poetry we can study the consequence of loanwords and syntactical arrangements from Arabic. Furthermore, as Arabic vocabulary has itself changed significantly through time, it is essential to keep in mind the deviations in norm and the different semantic relations of the same words when used in Persian and Arabic in different historical periods. An additional factor in the transition of Middle to Modern Persian was the geographical range of this language in the awakening that accompanied the Arab invasion. Following the path of the Arab conquest, Persian spread from its heartlands to Central Asia (Transoxiana). For their conquests, the Arabs enlisted native peoples in their armed forces. These local populations did not speak a consistent Persian and in many cases did not even use Persian among themselves. Nevertheless, the Persian of the time served as a lingua franca for these recruited men. They spread this new version in the occupied provinces, from Azerbaijan to Central Asia, to the detriment of other Iranian languages and other dialects of Persian. Such was the case of Sughdian, a language belonging to an ancient culture that was mainly overwhelmed by Persian. Therefore Persian became, in time, the court language of the first semi-independent Muslim territories, most particularly those established in the Greater Khurāsān (Fouchecour, 2006).

With the arrival of translations and interpretations of the Qur'ān, Persian began to display its flexibility as a language for transmission of religious and spiritual considerations as well as administrative and cultural concerns (Lazard, 1983, p. 382). The geographical growth of the language now followed a new course, from Bukhara to Tabriz, and from Ghazna to Shiraz. For a while the province of Fārs in southern Persia sustained many of the distinct qualities of Middle Persian, while Central Asia, the first site of the new culture inspired by Islam, was for ten centuries the heartland of scientific and literary Persian. Throughout these lands, however, substantial elements of pre-Islamic Iranian culture were maintained, a critically important fact in the overall history and culture of the Islamic realm (Yarshater, 
1986).

Persian delivered to the Muslim world a wealth of Iranian art, stories, traditions, and mythologies as well as history, ethical teaching, political guidance, and religious essays rooted in the pre-Islamic period. The abundant literary accomplishments of the Abbasid age and the notable sparkle of Muslim mysticism are indebted to the Iranian input, completed through the medium of the Arabic language (Fouchecour, 2006).

Ṭabarī (d. 923/1521), in his two monumental works History and Tafsir (commentary on the Qur'ān), and the great anthologist and scholar from Nayshābūr, Abū Manșūr Ṭa ālabī (d. 440/1038), in his creative writings on literature and ethics and behavior, are expressive representatives of this deeply rooted Persian presence.

By start of the ninth century, Persian was being shaped from a somewhat different direction, this time by the Turks. Soon after the Umayyad period, High Turkish officials and ranked officers were a relentless feature of the Persian political and military structure, always close to the rulers. In the northeastern provinces of Persia, the system of ghulāms (slavery) demanded the association of Turks in Muslim militaries. They became Muslims, adopted the Persian language, and began to move up the military ladder. Conquerors of a state that in one century extended from Baghdad to Anatolia and to the Indus, the Turks in turn were won over by Persian culture, while maintaining control of their new states for centuries. After them, Mongol and Mughal patrons nurtured the same customs and explored the same heritage (Riyāhịi, 1990).

If Tamerlane gathered an elite coterie of scientists, artists, and men of letters in Samarqand by force and oppression, his heirs through generous sponsorship shrewdly made the Herat of the fifteenth century a supreme center of the Persian literary world. The prevalent admiration and impact of the ample poetry of 'Abdu'l Raḥmān Jāmī (d. 894/1492), spreading from Herat to India and into the Near East, is a noteworthy example of this cultural proliferation. Even today, Istanbul remains a treasury of Persian manuscripts (Riyāhī, 1990). Set between two seas and a gulf, the Iranian highland provided a perfect setting for the exchange of cultures-its own spreading west to the Mesopotamian rivers and east to the Oxus (Āmū Daryā) and the Indus (Fitzherbert, 1996).

\section{The Early Period of Persian Poetry}

In Persian literature, the difference between poetry and prose has always been obvious and rather deliberate, with poetry almost always taking precedence. It distinguishes itself from prose not only through rhyme and rhythm but also through the ingenious play between clear connotation and inherent nuance. For Ehsan Yarshater, a fairly extensive prose literature, mainly of narrative, anecdotal, and moralizing kind also flourished, but it is overshadowed by poetry in terms of quality and quantity alike. In fact, poetry is the art par excellence of Persia, and her salient cultural achievement. Despite their considerable accomplishments in painting, pottery, textiles, and architecture, in no other field have the Persians succeeded in achieving the same degree of eminence (Yarshater, 1988). 
Abū 'Abdullāh Ja'far Rūdakī (d. 342/940) (Shafî̀ ī-Kadkanī, 1350/1971), originally from Rūdak near Samarqand, was committed to the court of the Sāmānids Nașr b. Aḥmad (r. 266-94/864-92) at Bukhārā. Also a singer artist and a musician (Rypka, 1968), he stands without a doubt at the summit of the history of Persian poetry (Thackston, 1994). His surviving works (the versified Indian Bidpai fables otherwise known as Kalila va Dimna), composed at the court of the Sāmānids in Bukhārā, are the first chefs d'oeuvre of Persian poetry (Nafisī, 1962), serving as a model for later generations (Thackston, 1994).

This testifies to how a great poet created his art at the beginning of the eleventh century. As we have seen, a division of labor was still at work-poet, copyist, and storyteller were three different functions. Minstrels and wandering musicians in the West followed similar patterns. Arabic poetry began before the arrival of Islam in fifth and sixth centuries, and its first centuries following the rise of Islam have been the subject of abundant debate and investigation. The historical patterns of Persian poetry are quite different. The Parthians of the pre-Islamic era were minstrels who often performed at traditional events and banquets, telling epic tales and reciting lyric poetry (Boyce, 1957). They offered material and motivation for later works of classical Persian literature such as Vis u Rāmin, the tale of two lovers (Note 1). Some Zoroastrian and Buddhist texts have also survived from the early days of Persian literature (Melikian-Chirvani, 1974). The Iranians certainly added richness to Arabic literature in various fields. Arabic literature reached its summit during the 'Abbāsid culture (c. 750-860/1348-1458), to which Iranians had made a vital contribution: the prose writer 'Abdullāh b. al-Muqqafa' (killed c. 142/759-60), the jurist and first of four authorized Imāms Ḥanīfa (d. c. 150/767), the linguist Sibavayhī (d. 166/782), the disbeliever, poet, and satirist al-Bashshār b. Burd (killed 167/783), and the poet Abū Nuvās (d. 198/810) can be numbered among its most brilliant exponents (Rypka, 1968).

A Persian poem is shaped to delight the eye as well as the ear. Behind the art are rules and skills that already appear to be deeply rooted in the works of Rūdakī. References by Shams-i Qays Rāzī (d. circa 628/1226) (Dihkhudā, Lughat-nāma, 1373/1994), however, suggest that there was a period of less skillful literary production before Rūdakī emerged. At first, the obstacles appeared to be of a practical nature; theory was to follow. In practice, in terms of rhythm, one moved from a pre-Islamic poetry dependent on interchanging strains, seldom returning to the ictus (stress on a syllable in a line of verse), to a poetry based on the variation of long and short syllables, as in Arabic poetry (Fouchecour, 2006). We are better able to reconstitute these moments of change and retrenchment, in which the ancient rhythms were reinterpreted as new rhythms, and doctrines of Arabic rhyme triumphed once the Arabic alphabet was accepted (Lazard, 1983, p. 382) In the poems of Rūdakī, the new technique seems thoroughly concealed in writing that is certain and vibrant, yet malleable for this period. It was not until the twentieth century that Rūdakī's prosody became outdated and called into question. By supporting different schools of poetry, the era's princes contributed to the formation of enduring mores, such as the Khurāsānī, 'Irāqī, Azerbaijani, and Hindi (Indian).

Court poets ever since Rūdakī, or poets reciting their verses on religious occurrences or in Sufi congregations since at least Abū Sa id Abu al-Khayr (d. 440/1038) (Abū Sa'id Abu al-Khayr, 1366/1988) 
in the early eleventh century, had to present themselves before an audience and prove their worth. The spectators were able to judge the poet's art and technique immediately, and they particularly valued his ability to extemporize in public. Creativity (badiha-sara ${ }^{\prime} i$ ) could elicit instant appreciation for a great poet such as Farrukhī (d. 429/1027). Art, technique, and improvisation were means through which the poet encountered the expectations of his audience and, drawing on his own erudition to exert his authority, sought to reshape prevailing poetic traditions.

\section{Technical Principles of Persian Poetry}

The fundamental unit of a Persian poem is a line of verse comprised of two parts, each containing the same number of syllables and set to the same rhythm. In keeping with Arabic poetry, this distich form is called a bayt (couplet), with the long and short syllables arranged according to set structures. The principles of these patterns are also borrowed from Arabic, though we must bear in mind that the great Persian meters are not very common in Arabic and are most likely modified from ancient Persian stress systems. Such is the case of the quatrain, the ruba ${ }^{\prime} \bar{l}$, so typical of Persian and known before Islam (Elwell-Sutton, 1986). It is also the case for the mutaqārib, a reinterpretation of a stressed rhythm found in Middle Persian and the meter used for many famous long narrative poems in Persian, including Firdawsī's Shāh näma. The specific use of this meter and some others is in itself a perfect illustration of the way literary genres existed and differed markedly from each other in their use of meters. The splendor of a Persian poem, however, also lies in its public oration (a fairly fresh and significant area for research), where many other factors interfere. Sequentially, rhyme is needed for the poetic effect of a Persian poem. It was the imitation of Arabic poetry that led to its extensive use. A simple voiced refrain at first, it soon became more difficult and organized.

In Persian poetry, the arrangement of rhymes defines the poem's form. A form is considered to be classical when both parts of the first bayt rhyme. The most common and simple poem consists of two bayts (the quatrain), the second of which must rhyme with the first. Usually the first bayt (or distich) of the entire poem conveys the rhyme, its two hemistiches rhyming with each other (Fouchecour, 2006). The mathnawi is a form of unusual meter whose every hemistich rhymes with its matching part and whose rhyme changes with each line. It is consequently free from the limitations of monorhyme and flexible enough to be used in long poems. In contrast, in the ghazal, also in a special meter, all the bayts rhyme, and ghazals are, in contrast to mathnawiss, rather short. The qașida, an older and more advanced form than the ghazal, bears a resemblance to the latter in form. It is also in monorhyme but can conform significantly in length and generally includes three separate thematic portions. We should note that the qașida, the ghazal, and the quatrain were the three forms on which Persian medieval handbooks dealing with eloquence, prosody, and poetic descriptions focused (frequently echoing Arabic manuals), and quotations from them were the center of examination, giving them an advantaged place relative to other vital forms, most particularly that of the mathnawi and its diverse subject matter, which received rather less consideration in the earlier works on poetry (Schimmel, 1992). 


\section{Poetic Genres}

According to Ahmed Ateș, its editor, Rāduyān̄̄s Tarjumān al-Balāgha (Dragoman of Eloquence) may have been written at a Qarakhānid court shortly before 508/1114, the date of the unique manuscript (Ṣafâ, 1380/2001). It was composed for a Persian-speaking audience who perhaps knew little Arabic. Rāduyānī claims that it is the first work on rhetoric to be written in Persian, although as he says, it follows an Arabic model, that of the Mahāsin al-Kalām (Beauties of Speech) by Nāṣir Abu'l-Hasan al-Marghinānī (d. 599/1197) (Tetley, 2009). For Rāduyānī in the eleventh century, and Rashid al-Din Wațwāt (d. 584/1182) (Ṣafā, 1380/2001) in the twelfth (the first writers of treatises on Persian poetry), meter and rhyme were such all-embracing characteristics of Persian poetry that the two authors did not think it necessary to dwell on them. Their manuals deal with important rhetorical figures of Persian poetry and reveal a debt to earlier Arabic treatises concerned with Arabic poetry. But although the terminology is derived from Arabic, the selection itself and the numerous Persian examples bear witness to a well-established and original practice. Shams-i Qays, in the thirteenth century, was acquainted with the works of his forerunners and built on them. His point of departure was also the practice of Persian poets. His taxonomy is so rich in references that his discourse can also be viewed as a treasury of poetry (Fouchecour, 2006). The finest work in this genre was written in the fifteenth century by Husayn Wāe iz-i Kāshifî (d. 910/1504) (Dihkhudā, Lughat-nāma, 1373/1994), a friend and disciple of Jāmī, a man held in very high esteem in the Timūrīd court at Herat (Simidchieva, 2003).

For Kāshifĩ and the tradition before him, the perfection of a poem lies in the notion of tafwif (allegorical alliteration) (Note 2), not the usual aporia (Note 3) used as a rhetorical device in literature. "The importance of literature ... lies in its power to extend boundaries by destroying conventional frames of reality, revealing thereby their historically transient nature. Great literary texts, with or without the awareness of their authors, always deconstruct their apparent message by introducing an aporia (undecidable) which the constructive reading must unravel" (Preminger, 1993). The poet should be able to effortlessly intertwine and bring together all the needed rudiments in a poem—rhyme, rhythm, words, expression, and meaning - so that they produce a cohesive body. In short, in its melodious structure a poem should look like a stunning tapestry. To Shams-i Qays's requirements, Kāshifĩ adds that a flawless poem must be covered with exquisite stones (the literary figure of tarși ${ }^{\circ}$ ) (Yarshater, 1988), suggesting that the words of the poem should be in total harmony in their rhyme and concluding letters. This literary figure would be at its most perfect if the words echoed each other in their consonants and vowels, all the while differing in meaning (the poetic figure of tajnis-i tāmm) (Subtelny, 2011). In total, the talented poet's palette includes ninety-five rhetorical figures. In the list of rudiments most appreciated by our scholars, we find, in order of precedence in their treatises, letters, then words followed by phrases, and lastly the poem perceived as a whole. The other foremost concern is the script itself. The key role of calligraphy, including the shape of the letters, is evident and much debated throughout the handbooks on poetry.

The examination of thematic genres in Persian poetry requires further study, given the riches of the 
material and the numerous allusions in traditional manuals and anthologies. Wațwāt and Kāshifî, for example, refer to "collective discourse" (kalām-i jāmi'), a moral analysis of the variations of life, a poem consisting of encouragement, counsel, or grievance against fate and the flow of events, and a narration of notable events in different periods (Subtelny, 2011, p. 146; Fouchecour, 2006).

Wațāṭ had praised Mas'ūd-i Sa'd-i Salmān (d. 515/1121-22) (Note 4) for the way his poems from prison (habsiyāt) excelled at kalām-i jāmi' (a fusion of complaint and advice) (Wațwāț, 1929). One still speaks of bahāriya (descriptions of spring), fakhriya (poems of heroic boasting), shakwā'iya (laments of separation from the beloved), and marthia (mournful odes). The poet is judged by the way he deals with a genre in a given set of environments. His poetic skills are a social marvel, an uttered form put into script, a text to be declaimed in a culture in which the memory and the ear, as well as the eye favored by the art of calligraphy, all play in harmonious unity.

\section{Pedagogic Facets of Persian Literature}

Few Persian texts fail to offer some sort of advice. Some do so openly as their explicit purpose. Others express their moral indirectly through tales. This is mainly true of historical works. They infuse the events with meaning and importance, submit codes of social and moral behavior, and endeavor to create a sense of collective compromise based on their principles.

The art of rhetoric is the art of inducement, which is why it is allied to the art of poesy, as in Persian literature. The beauty of these writings has bewitched many generations and interested them in the didactic messages the works transmit. The communicative power of these interpretations (hikäyat, qișsa, tale, fable, and romance) first amuses readers, then stimulates their aspiration to learn, and ultimately influences their views, moods, spirits, and personalities. The message conveyed may be firmly ethical or have to do with honor or politics. It may even be divine in nature. The shortest and most common form of story is the hikāyat, a narrative to be told. Its fruit is an exemplum, drawn from experience and expressed in such a way that it can simply be engraved in memory. The exemplum is entrenched in the discourse or the tale of the behavior of one or more characters in a story.

The famous Tadhkirat al-awliyā' (Memoires of Saints) by 'Atțār (d. c. 623/1221), written in the twelfth century, brings together a series of works first created from biographies of saints and intended as spiritual guidance. Other collections of stories appeared later, containing short stories on different themes not necessarily limited to strict sacred or mystical concepts. The first work to have reached us in this form was authored by Sadid al-Din 'Awfi circa 635/1233. His Jawāma' al-hikāyat (Collected Stories) is significant for its classification of tales rendering their subject matter (Nizām al-Din). In India, it served as a collection presenting some of the best models of stories from Persian sources and background.

Another kind of anthology provided a more thoughtful educational outline to a selection of narratives. Jalāl-al-Din Rumi (d. 675/1273) believed that "speech that rises from the soul, veils the soul" (Lewis, 2000). His Mathnawi-i ma'nawī, divided into six books, is the ultimate model. Finally, there are stories created to impart a message of wisdom and teach a lesson. In one or more lengthy versions that serve as 
an overall frame story, other shorter stories are organized. This is the case with some of the famous Persian Mirrors for Princes.

One may cite the pattern of three renowned works composed as Jawäma al-hikāyat. The Thousand Tales (Hizār afsān), which has not survived but was celebrated by the tenth-century Arab intellectual Ibn al-Nadim (d. c 397/995), (Nicholson, 1907; Nicolson, 1934) had the same frame story as the Thousand and One Nights. "Kalila va Dimna" is the title of the first story in a very dated compilation of lengthy stories of Indian derivation. The script was changed into Middle Persian at the court of Khawsru Parviz and then translated into Arabic and Persian (Blois, 1990). It is not a frame story, but its educational insertion offers a clear harmony. Each story deals with a theme intended to instruct the prince and his patrons. Finally, Dāstān-i Samak-i 'ayyār (The Tale of Samak the Gallant-Trickster) is an old Persian tale. Committed to writing from the twelfth century onward, it preserves its oral structure, a very long account divided into fairly free and divisible parts. Indeed, it is a difficult twin story-the tale of a prince and of Samak, the leader of a group of young men unified by pact of loyalty. It has its roots in an old institution (school) harking back to the Sāsāniān period (Zakeri, 1993).

In the twelfth century the book of Kalila va Dimna, taking its title from its first tale, achieved great linguistic distinction in the version by Nașr Allāh Munshī, a court patron of the Ghaznavid. This version served as a model for other story collections. Marzbān-nāma, for example, written in thirteenth century in fine Persian, brings together tales known from the tenth century from the province of Tabaristān. The collection Sandbād-nāma, written by Zahirī Samarqandī (d. c. 600/1198), was produced in India and translated into Middle Persian. It tells of seven viziers who in seven days must rescue a young prince from death and absolve him of fabricated charges of seduction. The book is a political discourse covering a favored medieval theme, "the trickeries of women". Another example of such a structure is the book of Bakhtiār, originating in a Middle Persian source translated into Arabic and later into Persian. Here the transgressions of the main characters (also viziers) are condemned in ten beautifully written tales.

Written around 1082, the Qābus-nāma by Prince Kaykāvūs of Țabaristān delivers a different kind of reflection and often suggests satirical advice. The different stories, exaggerated in elegant prose, are taken from the historiography of the period and support the rational statements in the book. The Qābus-nāma comprises forty-three chapters that deal with ethics, conduct, and traditions consecutively and describe numerous professions and careers. A last and totally different chapter is an important treatise on noble and gallant behavior in the kind of milieu visited by Samak.

At the end of the eleventh century, Nizām al-Mulk (Note 5), the famous vizier of the Saljūq, wrote his Siyar al-mulūk or Siyāsat-nāma (Book of Government or Rules for Kings), a seminal collection of modest yet elegant political remarks on contemporary history (Fouchecour, 2006). Nașịhat al-mulūk (Advice to Kings) was completed by the great theologian Muhammad Ghazālī circa 507/1105 (Note 6). Its introduction sets forth the basics of faith and devotion for an influential prince. Seven eloquent chapters stylistically composed then study the employment of power and its consequences; the book is a classic of its type. Also worth citing is Aghräd al-Siyāsat (The Book of Political Ambitions), written shortly after 
559/1157 by Zahirī Samarqandī. It is a part-legendary, part-historical account of seventy-four kings and their lives and maxims.

A traditional literature of tersely phrased statements of truth or opinion, similar to proverbs, has existed in Persian literature since before the dawn of Islam. Firdawsî's Book of Kings contains many collections of ethical and dogmatic advice, referring to moral and political issues that originate in Middle Persian sources. In about 347/945, Abū Shakur wrote a long didactic poem composed of proverbs, which fortunately has survived (Note 7).

Sufi texts drew deeply on other collections. Well-known Persian works such as Ghazālī’s Kimiyā-yi sa'ādat (Alchemy of Prosperity), Sanā’’’’s Hadiqat al Haqiqa (The Garden of Truth), and Sa dì's Gulistān (Rose Garden) are all indebted to such literature. Niẓāmī took a groundbreaking approach by collecting his own statements of counsel to express that, although challenged by their fate, human beings are nonetheless able to strive toward intellectual and moral righteousness (Zarrinkūb, 1388/2009).

The ultimate legacy of these saints was to build a language of morals in Persian that would stimulate subsequent cohorts and give them a vehicle for further allegory. Later, in the fourteenth century, a period of political mayhem, the satirical work of 'Ubayd-i Zākānī (702/1300-773/1371) depicted a morality turned immoral, ridiculing society in a way that would have seemed distorted to earlier generations (Browne, 1909). Here is one such example of his poetry:

Kings to gain a single object oft will slay a hundred souls.

And they further say: "Justice bequeaths disaster" (Browne, 1909).

\section{The Impact of Sufism on Persian Literature}

The standardization of mystical language and the increasingly overt use of allegory became distinctive features of mystical poetry, in particular during the fourteenth century (Bruijn, 1997). Sufism played a key part in the Islamization of the Persian world. The literary appearance of its principle matched its didactic attitude, which involved introducing, then guiding its audience on the mystical path. Its sacred strength encouraged monumental works in Persian literature. Sufism pursued the excellence and perfection of the soul. Moving from austerity to asceticism, it promoted the path of love. It impelled its observers to reach beyond themselves, teaching them to know the true self. Sufism could also lead to a form of elated spirituality. Literary works followed to guide the explorer along the path. One must recall here that two schools of Greek philosophy, Stoicism and Neoplatonism, had a great impact on the development of the three monotheistic traditions.

Basically, Sufism is an affiliation between an Elder/Master and his devotee, between the Beloved as the heralding spirit and the Lover as the pursuer. A number of Sufi movements were shaped on the foundation of this association after the thirteenth century. Two Sufi trends first arose in Persia. In the partially Islamized rural environment of Khurāsān, Abū ‘Abdullāh Muḥammad Ibn Kirrām (d. 255/853) (Shafi ${ }^{\top} \overline{1}-K a d k a n \overline{1}, 1385$ ) directed a pietistic movement with many supporters. Around the same time, Hamdun al-Qaș̣āar (d. 286/884) fortified a form of devotion that pursued self-blame as a form of 
abstinence. This malāmatī (blameworthy) movement significantly swayed Persian Sufism and its literary creation. The poetry of Hāfiz, who in fact was not a Sufi, can be interpreted from this viewpoint. Many modern critics (including Muțahharī and Purjawādī), although not necessarily viewing Ḥâ̄iz as a follower of a Sufi order, perceive him as a mystic 'arif (gnostic) (Note 8). Therefore, his accounts of wine, sin, and music, as well as his references to desire and pleasure, are read as unvaryingly metaphorical, even mystical. Allusions to sin and erotic pleasure in his work are seen to be part of a sumptuous code of symbols (Note 9). In this view, H.âfiz's character as a rind (an inspired libertine) and his revolt against religious authorities, including Sufis, are symbols of malāmatī trends in Sufism (Lewis, 2000, pp. 483-491).

The Kirrāmī movement encountered resistance and was eventually defeated because of its political associations (Shafí '⿳- Kadkan̄i, 1350/1971). In this early period of Sufism's spread appeared a great and lonely, though often-visited, master, Bāyazid Bastāmī (d. 276/874). He left behind a legacy of adages in Persian that continue to resonate. In them one senses an Indian inspiration and the greatly advanced awareness of one who has reached union with God.

At the beginning of the following century a remarkable figure, Manșūr Ḥallāj, found Khurāsān receptive to his radical form of mysticism (Zarrinkūb, 1377/1998, pp. 15-30). He was eventually martyred in Baghdad in 324/922 for daring to affirm his union with the Ultimate Truth (God). Mystical love, the source of all literary manifestation in Persian Sufism, rightly declared itself with Ḥallāj. A third significant stage in the history of Persian Sufism arose with the colossal work in Arabic of Ibn al- 'Arabī, who was born in Murcia, traveled much, and finally settled in Anatolia. He died in 638/1240, at the time when Jalāl-al-Din Rumi was in Konya (Chittick, 1989, p. 2). His disciple and interpreter, Șadr-al-Din Qunyavī (d. 676/1274), spread his master's teachings all over the Iranian cultural world. For instance, Jāmī's literary production during the fifteenth century was completed under the inspiration of the Andalusian master and set the prime direction of Sufi beliefs in Sunnism to this day.

As Sufism matured, it became entrenched in orders. This was accomplished not by Jalāl-al-Din Rumi but by his son and successor, Sultān Walad. The author of numerous works, Walad is the true founder of the Mawlaviya order. Mawlavī died in Konya in 675/1273 (Halman, 1988, p. 190). Șadr-al-Din Qunyavī, who died in 676/1274, knew both masters. 'Irāqī of Hamadān (d. 691/1289), who had returned from Multan in India, also settled in Konya. He knew Qunyavī, and his poetry and didactic work in prose, Lama'ät (Flashes), were influenced by the doctrines of Ibn al- 'Arabī. 'Irāqī contributed to the eastward expansion of Persian Sufism, which was then flourishing in Anatolia. Ghazals by 'Irāqī are among the most often sung today. However, 'Irāqī's spiritual contribution is linked to the specifically Iranian tradition that developed from Ḥallāj and such masters as Aḥmad Ghazālī (Fouchecour, 2006).

\section{The Summit of Classical Persian Literature}

Jalāl-al-Din Rumi (1207-73) (Halman, 1988, p. 190) and Sa dì (c. 1209-91) lived in the same century. Sheltered in Konya, Rumi had introduced mysticism from Khurāsān. Sa dī lived in Fārs, a province 
under the government of the Salghürid that had not witnessed the cultural separation and social chaos suffered by other provinces during the Mongol destruction. Sa dì's work is a highpoint in the historical growth of Persian literature. The thirteenth century also witnessed the beginning of Persian literature's spread in India. It was a splendid century of Persian prose widely used by historians in the court of the Mongols (Fouchecour, 2006).

Sa dî̀'s work in Shiraz is at the convergence of somewhat diverse literary genres and styles-narrative, moral, and political - as well as of the majority of Sufism's classical literary manifestation. His most important works, the Sa'dī-nāma (later titled the Bustān) and the Gulistān, are a perfectly unified tapestry of stories and narratives with explanation (Zarrinkūb, 1379/2000, p. 46) By this time, Sa'dī must have been over fifty, a middle-aged poet whose ghazals greatly influenced the writers who came after him. Without Sa dì's poems, we would not have the great ghazals of the subsequent century, particularly those of Ḥāfiz (Zarrinkūb, 1379/2000, pp. 46-47). If he had not read Sa 'aī’s humorous language and ironic remarks, 'Ubayd-i Zākānī would not have produced his entertaining verses. During Sa'dī’s time his popularity stretched far beyond Fārs (Schimmel, 1988, pp. 214-216). With Sa ${ }^{\circledR}$ d̄i, an apparently natural but carefully hewn style, influenced by Arabic but firmly rooted in the everyday Persian of the time, served as an exemplarily simple aesthetic technique for ensuing generations. Similar to Nizāāī, Sa $\mathrm{d} \overline{\mathbf{l}}$ believed in the power of discourse and the significance of language. His work in many ways summed up the cultural attainments of the preceding three centuries (Schimmel, 1988, pp. 214-216).

Sa 'dī's work encompasses numerous subjective allusions and factual details. Nonetheless, here as elsewhere, one must distinguish between the man and the literary facade presented by the writer. This persona $\left(\mathrm{Sa}^{\mathrm{e}} \mathrm{d} \overline{\mathrm{i}}\right)$ would have visited the entire Islamic world, from North Africa to India. Sa ${ }^{e} \mathrm{~d} \overline{\mathrm{i}}$ was educated in Baghdad, made the pilgrimage to Mecca, and met important spiritual masters (Zarrinkūb, 1379/2000, pp. 62-64). Wisely, he returned to Shiraz at the beginning of the Mongol invasion in 658/1256; and two years later he dedicated the Bustān and then the Gulistān (unquestionably the fruit of many years' hard work) to Abu Bakr b. Sa 'd, the Salghūrid ruler. We sense Sa 'dī's understanding of the everyday lives of the people of Shiraz, associating with the court and its patrons, and maintaining links with spiritual movements in the capital. More conventional in style than the Gulistān, the Bustān consists of extended informative and educational poems in nine chapters, dealing throughout with the fairness and caring deeds of the prince, with worldly and divine love, arrogance, recognition of fate as determined by wisdom, teaching, recognition, and penitence (Thackston, 1994, p. 47). But all this is cast in an ocean of tales expressed in stunning dialect (Katouzian, 1358/1979, pp. 204-205). The Gulistān elegantly delivers teachings in the form of sessions. Transcribed chiefly in prose, these are narratives taken from daily life that elucidate a lesson refined in a couple of beautifully composed verses (Note 10). For Sa ${ }^{e} \mathrm{~d} \overline{\text { two }}$ characters prevail in society: the king and the dervish. They signify the foundations of society: political authority and religious associations. Traditional Iranian thought opposed the Greek vision of the prince-philosopher but later adapted it with the stipulation that no prince can act perceptively without a counsellor. This became the political validation for Persian literature itself, as it revealed its own 
capabilities as just such a mentor (Fouchecour, 2006, p. 70).

\section{References}

Abrams, M. H. (1999). A Golossary of Literary Terms. In s.v. “Alienation Effect”. Massachusetts: Earl McPeek.

Alexander, J. E. (1827). Travels from India to England. London: Ulan.

Al-Ghazālī, Abū Ḥāmid Muḥammad. (2002). On Disciplining the Self (H. N. Seyyed, Ed.). Chicago, IL: Great Books of the Islamic World, Inc.

Alpers, S. L. (1960). Ekphrasis and Aesthetic Attitudes in Vasari's lives. Journal of the Warburg and Courtauld Institutes, 23, 196-199.

Arberry, A. J. (1958). Classical Persian Literature. London: Curzon.

Bahār, M. T. (1351/1932). Bahār va adab-i Fārsī: Majmu 'i-yi yikșad maqāla az Malik al-Shu 'arā-yi Bahār. Tehran: Kitabhā-yi Jibī.

Bal'amī, Abū 'Ali Muhammad. Tārikh-i Bal'amī (M. T. Bahār, Ed.). (1994). Tehran: Amir Kabīr.

Balay, C., Claire, K., \& Zhiva, V. (1995). Pand u Sukhan: Mélanges offerts à Charles-Henri de Fouchécour. Tehran: Institut Français de Recherche en Iran.

Banani, A. (1988). Ferdowsi and the Art of Tragic Epic (E. Yarshater, Ed.). Columbia Lectures on Iranian Studies, 3 .

Bausani, A., \& Antonino, P. (1960). Storia della letteratura persiana. Milan: Nuova Accademia.

Beaurecueil. (1965). Serge de Laugier de. Khwādja 'Abdullāh Anșāri: Mystique hanbalite. Beirut: Imprimerie Catholique.

Beelaert, A. L. F. A. (1996). A Cure for the Grieving: Studies on the Poetry of the 12th-Century Persian Court Poet Khāqānī Shirwānn̄. Netherlands: Netherlands Institute for the Near East.

Bertels, E. E. et al. (1988). Istoriya literatury i kul'tury. Moscow.

Beyond Faith and Infidelity: The Sufi Poetry and Teachings of Mahmud Shabistari. (1995). Richmond, UK: Curzon.

Blois, François. (1990). Burzoy's Voyage to India and the Origin of the Book of Kalīlah wa Dimnah. London: Royal Asiatic Society.

Bloom, J. M. (2001). Paper before Print: The History and Impact of Paper in the Islamic World. New Haven, CT: Yale University Press.

Bosworth, C. E. (1968). The Development of Persian Culture under the Early Ghaznavid.

Bowen, H., \& Bosworth, C. E. (2015, May 21). Nizām al-Mulk. In Encyclopaedia of Islam (2nd ed.).

Boyce, M. (1957). The Parthian Gōsān and the Iranian Minstrel Tradition. JRAS, 18, 10-45.

Boyle, J. A. (1974). The Chronology of Sa'dīs Years of Travel (R. Gramlich, Ed.). Wiesbaden, Germany.

Browne, E. G. (1909). A Literary History of Persia. London: T. Fisher Unwin.

Bruijn, J. T. P. de. (1997). Persian Sufi Poetry: An Introduction to the Mystical Use of Classical 
Persian Poems. Sufi Series. New York: Routledge.

Cerquiglini, B. (1989). Eloge de la variante: Histoire critique de la philologie. Paris.

Chalisova, Natalia. (2009). Rhetorical Figures. EIr. Retrieved May 6, 2014, from http://www.iranicaonline.org/articles/rhetorical-figures

Chaytor, H. J. (1945). From Script to Print: An Introduction to Medieval Literature. Cambridge: Cambridge University Press.

Chittick, W. C. (1979). Lama'at (Divine Flashes [of Fakhruddin 'Iraqi]). Gnosis, 23-46.

Chittick, W. C. (1981). Sufism. In J. Nurbakhsh (Ed.), Meaning, Knowledge, and Unity. New York: Khaniqah-i Nimatullahi.

Chittick, W. C. (1988). Tasawwuf. 2. Ibn 'Arabi and after in the Arabic and Persian Lands, and Beyond. $E I^{2}, 9,317-324$.

Chittick, W. C. (2000). Lawā'ih. In M. Sachiko (Ed.), Chinese Gleams of Sufi Light: Wang Taiyu's Great Learning of the Pure and Real and Liu Chih's Displaying the Concealment of the Real Realm. Albany: Suny Press.

Chittick, W. C. (2003). The Elexier of the Gnostics. In Islamic Translation Series. Provo, UT: Birmingham Young University Press.

Chittick, W. C., \& Wilson, P. L. (1982). Fakhruddin 'Iraqi: Divine Flashes. New York: Paulist (Classics of Western Spirituality).

Clinton, J. W. (1972). The Divan of Manūchihrī Dāmghānī: A Critical Study. Minneapolis: Bibliotheca Islamica.

Coleridge, S. T. (1983). In J. Engell, \& W. J. Bate (Eds.), Biographia Literaria or Biographical Sketches of My Literary Life and Opinions. London: Routlege \& Kegan Paul.

Cooper, J. (1998). Mulla Sadra Shīrāzi (E. Craig, Ed.). The Routledge Encyclopedi of Philosophy (Routledge), 6, 585-599.

Corbin, H. (1954). Avicenne et le récit visionnaire. Trask as Avicenna and the Visionary Recital. Tehran.

Corbin, H. (1980). Mulla Sadrā. Tehran: Jāvīdān.

Corzon, G. N. (1966). Persia and the Persian Questions. New York: Barns and Noble.

Culler, J. (1997). Literary Theory. Oxford: Oxford University Press.

Dabāshī, Ḥ. (1985). Didgāhī bi afkār-i ijtimāēīi Mullā Șadrā. Iran Nameh, 3(3), 407-429.

Dādbih, A. (1371/1993). mājirā-yi pāyān nāpazīr-i Ḥāfiz. māh-nāma-yi Kilk, 30, 228-230.

Dalāl, G. A. (1995). Ethics in Persian Poetry: With Special Reference to Timurid Period. New Delhi: Abhinav.

Danner, V. (1986). Arabic Literature in Iran. The Period from the Arab Invasion to the Saljuqs. In R. N. Frye (Ed.), The Cambridge History of Iran (pp. 566-594). Cambridge: Cambridge University Press.

Dashtī, 'A. (1385/2007). Kākh-i ibdā': Andishahā-yi gūnāgūn-i Hāafiz. Tehran: Shirkat-i Qalam. 
Davidson, O. M. (1994). Poet and Hero in the Persian Book of Kings. Ithaca, NY: Cornell University Press.

Davis, D. (1992). Epic and Sedition: The Case of Ferdowsi's Shāhnāmeh. Fayetteville: University of Arkansas Press.

Dick, Davis. Vis and Ramin. (1st ed.). (2008). Washington, D.C., U.S.A.: Mage.

Dihkhudā, 'A. A. Amthāl va hikam. (1352/1974). Tehran: Sipihr.

Dīvān-i Khwāja Ḥāfiż. (1362/1984). Dīvān-i Khwāja Shams al-Dīn Muhammad: Mulhaqāt-I ghazalīyāt, qașā id, mathnavìyyāt, qața 'āt va rubā '̄yā. Tehran: Khārazmī.

Edārati-Gilāni, Aḥmad. Shā'irān-i 'aṣr-i Rūdakī (A comprehensive account of poets in the 3rd-5th centuries A.H. which complements de Blois and Mudabbirī and Lazard, s.v. in providing a full account of the earliest specimens of poetry in Persian). (1991). Encyclopedia Iranica covers biographical articles on all key Persian writers as well as thematic articles on various genres and literary expressions, and so on. Tehran.

Elwell-Sutton, L. P. (1986). The 'Rubā'̄ì' in Early Persian Literature. In R. N. Frye (Ed.), The Period from the Arab Invasion to the Saljuqs (pp. 633-657). Cambridge: Cambridge University Press.

Faces of Love: Hafez and the Poets of Shiraz. (2012). Washington, D.C.: Mage.

FitzGerald's Salāmān and Absāl: A Study. (1956). Cambridge: Cambridge University Press.

Fitzherbert, T. (1996). Portrait of a Lost Leader: Jalal al-Din Khārazm Shāh and Juvain̄̄. In J. Raby, \& T. Fitzherbert (Eds.), The Court of the Il-khans, 1290-1340. Oxford: Oxford University Press.

Gulbun, M. (1351/1972). Bahar va adab-i Fārsī. Tehran: Kitābhā-yi Jībī.

Hâafiz az dīdgāhhāa-yi mukhtalif. (1364/1986). Tehran: Ādhar ābādigān.

Hāâtiz Shināsī. (1376/1997). Tehran: intishārāt-i pazhang.

Halman, T. S. (1988). Jalāl al-Din Rumi: Passions of the Mystic Mind (E. Yarshater, Ed.). Columbia Lectures on Iranian Studies, 3.

Hillmann, M. C. (1976). Unity in the Ghazals of Hafiz. Minneapolis: Biblioteca Islamica.

Hiravi, H. 'A. (1368/1990). Maqālāt-i Hāafiz. Tehran: Kitābsarā.

Hiravī, Ḥ. `A. (1371/1992). Majmū 'i-yi maqālāt, sukhan-i ahl-i dil. Tehran: intishārāt-i ufset.

Hiravī-Khurāsānī, M. (1368/1989). Maqālāt-i Hāfiz. Tehran: Kitābsarā.

Hiravī-Khurāsān̄̄, M. (1386/2008). Sharh-i ghazalhā-yi Hăfiż. Tehran: nashr-i naw.

History of Iranian Literature (K. Jahn, Ed.). (1968). Dordrecht. Dordrecht, the Netherlands: D. Reide.

Ḥujjatī, Ḥ. (2001). Urfî-i Shīrāzì. In Ḥasan Anūshā (Ed.), Dānishnāma-i adab-i fārsī, 1760-1764. Tehran.

Humā'̄ì, J. (1363/1985). Funūn-i balāghat va șanā'āt-i adabī. Tehran: Intishārāt-i Tūs.

Hūman, M. (1325/1947). Hāafiz: Sukhan̄̄ chand dar bāra-yi taṣhịh-i Divān-i aū. Tehran: Firdawsī.

Imdād, Ḥ. (1341/1963). Shīrāz dar guzashta va hạal. Shīrāz: itihạdīya-yi maṭbūeātīi fărs.

Inqitā', N. (1387/2008). Häfiz va kish-i mihr: Shaydā-yi shūrida-yi Shīrāz, dar kārgāh-i kishī kuhan. Tehran: Shirkat-i Kitāb. 
Iran under the Safavids. (1980). Cambridge: Cambridge University Press.

Jāmī. (1977). Naqd al-nusūs fĩ sharh naqsh al-fusūs. In Persian and Arabic text with critical apparatus, notes, English and Persian introductions, indexes. Tehran: Imperial Iranian Academy of Philosophy.

Javad, Nūrbakhsh. (1372/1993). Farhang-i Nūrbakhsh, Ișțilāhāt-i tașawwuf. Tehran: Marvī.

Juvain̄̄, 'Alā' al-Din 'Ațā Malik. (1958). Tārikh-i jahāngushā. Boyle as The History of the World-Conqueror, 2(3).

Kamāl Kojandī. (2010). Encyclopaedia Iranica, XIV/4, 412-414.

Karīm Khān Zand: A History of Iran, 1774-1779. (1979). Chicago: University of Chicago Press.

Katouzian, H. (1358/1979). Sa'dī Shā' 'ir-i 'Ishq va zindagī. Tehran: Nashr-i Markaz.

Khurramshahi, B. (2002). Hafiz's life and Times. New York: Encyclopedia Iranica.

Kirmānī, S. N. (1373/1995). Dawlat-i pīr-i mughān bād kih bāqū sahl as: Majmū'a-yi maqālāt-i Hâafiz-shināsī. Tehran: pāzhang.

Kutbī, M. (1374/1996). Sharh-i 'irfānīi ghazalhā-yi Hāâiz (K. Manșūī, Ḥ. M. Amīn, \& B. Khorramshāhi, Eds.). Tehran: Qațra.

Lārī, Raḍī al-Dīn 'Abd al-Ghafūr. (1343/1964). Takmila-yi nafahāt al-uns (Bashīr Hiravī, Ed.). Kabul: Anjuman-i Jāmī.

Lazard, G. (Ed.). (1983). Abu Sakur Balki. Encyclopaedia Iranica. Retrieved May 6, 2014, from http://www.iranicaonline.org/articles/abu-sakur-balki-poet-of-the-samanid-period

Leaf, W. (1898). Versions from Häfiz: An Essay in Persian Metre. London: Grant Richards.

Lees, W. N. (1859). A Biographical Sketch of the Mystic Philosopher and Poet Jami. Calcutta: W. N. Lees.

Lentz, T. W., \& G. D. Lowry. (1989). Timur and the Princely Vision: Persian Art and Culture in the Fifteenth Century. Los Angeles: Los Angeles County Museum of Art; Washington, DC: Arthur M. Sackler Gallery.

Levy, R. (1969). An Introduction to Persian Literature. New York: Columbia University Press.

Lewis, F. (2002). Hafez ix. Hafez and Music. Encyclopaedia Iranica. Retrieved September 12, 2011, from http://www.iranicaonline.org/articles/hafez-ix

Lewisohn, L. (1992). The Life and Times of Kamal Khojandi. Iran Nameh, 10(4), 39.

Lewisohn, L. (1993). Țariq-i Sufiāna-yi ma rifat. Iran Nameh, 11, 129-136.

Lewisohn, L. (1998). An Introduction to the History of Modern Persian Sufism, Part I: The Ni'mat-Ullāhī Order: Persecution, Revival and Schism. Bulletin of the School of Oriental \& African Studies, 61.

Lewisohn, L. (2010). Prolegomenon. In Hăfiz and the Religion of Love. London: I. B. Tauris.

Lewisohn, L., \& Bly, R. (1391/2012). Sī ghazal az Hâafiz: Dūsh dīdam ki malà’ik dar-i maykhāna zadand. Tehran: nashr-i markaz.

Limbert, J. (2004). Shìrāz in the Age of Hafez: The Glory of a Medieval Persian City. Seattle: 
University of Washington Press.

Lockhart, L. (1986). European Contacts with Persia, 1350-1736. In P. Jackson, \& L. Lockhart (Eds.), The Cambridge History of Iran, The Timurid and Safavid Periods (pp. 373-412). Cambridge: University Press.

Loloi, P. (2004). Master of Persian Poetry: A Critical Bibliography. London: I. B. Tauris.

Loloi, P., \& William, O. (2013). Poems from the Divan of Hafez. South Devon, UK: Acumen.

Losensky, P. E. (2008). Jāmī i. Life and Works. Encyclopaedia Iranica, XIV/5, 469-475.

Lughat-nāma (M. Mu īn, \& M. Ja far Shahidi, Eds.). (1373/1994). Tehran: Mu’assissi-yi Lughat-nāma.

Mahjūū, M. J. (1363/1985). Sabk-i khurāsāñ̄ dar shi 'r-i fārsī: Bar rasī-i mukhtașsātt-i shi 'r-i fārsī, az $\bar{a} g h \bar{a} z-i$ zuhūr tā pāyān-i qarn-i panjum-i hijri. Tehran: Firdawsī.

Makki, H. (1370/1951). Gulistān-i adab. Tehran: Kitābāfarin.

Mallāḥ, Ḥ. `A. (1363/1984). Manūchihrī Dāmghānī va mūsīqū. Tehran: intishārāt-I hunar va farhang.

Mancini-Lander, D. J. (2012). Memory on the Boundaries of Empire: Narrating Place in the Early Modern Local Historiography of Yazd. University of Michigan.

Manz, B. F. (1998, April). Temür and the Problem of a Conqueror's Legacy. Journal of the Royal Asiatic Society, 8(1), 25.

Massignon, L. (1994). Hallāj: Mystic and Martyr (H. Mason, Ed., Trans.). Princeton, NJ: Princeton University Press.

Maṣūmī, R. (1366/1987). Haft shahr-i 'ishq shāmil-i haft Divān-i kāmil. Tehran: Intishārāt-i Hāfiz.

Matthee, R. (1998). Iran's Ottoman Diplomacy during the Reign of Shah Sulayman I. 1077-1105/1666-94. In K. Eslami (Ed.), Iran and Iranian Studies: Essays in Honor of Iraj Afshar (pp. 148-177). Princeton, NJ: Zagros.

Medieval Persian Court Poetry. (1987). Princeton, NJ: Princeton University Press.

Meisami, J. S. (2002). Hafez v. Manuscripts of Hafez. Encyclopaedia Iranica, XI/5, 476-479.

Melikian-Chirvani, A. S. (1974). L'évocation littéraire du bouddhisme dans l'Iran musulman. Le Monde Iranien et l'Islam, 2, 1-72.

Melville, C. (1998). History and Literature in Iran. Cambridge: Cambridge University Press.

Meskūb, S. (1992). Iranian Nationality and the Persian Language. Washington, DC: Mage.

Microsoft Encarta Premium. (2006). Encyclopedia.

Mysticism vs. Philosophy in Earlier Islamic History: The al-Tūsī, al-Qūnawī Correspondence. (1981). Religious Studies, 17, 87-104.

Nasr, S. H. (1986). Spiritual Movements, Philosophy and Theology in the Safavid Period. In P. Jackson, \& L. Lockhart (Eds.), The Cambridge History of Iran, The Timurid and Safavid Periods (pp. 656-698). Cambridge: Cambridge University Press.

Nasr, S. H. (1986). The Religious Sciences. In R. N. Frye (Ed.), The Cambridge History of Iran, The Period from the Arab Invasion to the Saljuqs (pp. 465-481). Cambridge: Cambridge University Press. 
Nicholson, R. A. (1907). A Literary History of the Arabs. New York: Charles Scribner's Sons.

Nicolson, H. C. (1934). The Last Phase, 1919-1925. Boston: Boston University Press.

Palmer, E. H. (1974). Oriental Mysticism. London: Octagon.

Perkins, D. (1993). Is Literary History Possible? Baltimore.

Perry, J. R. (1998). Esmā̄īl III Șafawī. Encyclopaedia Iranica, VIII/6, 636.

Preminger, A., \& Brogan, T. V. F. (1993). The New Princeton Encyclopedia of Poetry and Poetics. Princeton, NJ: Princeton University Press.

Quinn, S. A. (2000). Historical Writing during the Reign of Shah Abbas. Salt Lake City: University of Utah Press.

Rahman, F. (2000). Revival and Reform in Islam: A Study of Islamic Fundamentalism. Oxford: Oneworld.

Rahnema, A. (1998). An Islamic Utopian: A Political Biography of Ali Shari atī. London: I. B. Tauris.

Ridgeon, L. (2006). Sufi Castigator: Ahmad Kasravi and the Iranian Mystical Tradition. London: Routledge Taylor \& Francis.

Roemer, H. (1986). The Jalayirids, Muzaffarids and Sarbadārs. In P. Jackson, \& L. Lockhart (Eds.), The Cambridge History of Iran, The Timurid and Safavid Periods (p. 193). Cambridge: Cambridge University Press.

Rumi Past and Present, East and West: The Life, Teachings and Poetry of Jalāl al-Dīn Rumi. (2000). Oxford: Oneworld.

Rypka, J. (1968). History of Iranian Literature. Dordrecht, the Netherlands: D. Reidel.

Sadr al-Dīn Qūnawī on the Oneness of Being. (1981). International Philosophical Quarterly, 21, 171-184.

Safa, Z. (1986). Persian Literature in the Timurid and Turkmen Period. In P. Jackson, \& L. Lockhart (Eds.), The Cambridge History of Iran, The Timurid and Safavid Periods (pp. 913-929). Cambridge: Cambridge University Press.

Savory, R. (1986). The Safavid Administrative System. In P. Jackson, \& L. Lockhart (Eds.), The Cambridge History of Iran, The Timurid and Safavid Periods (pp. 351-372). Cambridge: Cambridge University Press.

Schimmel, A. (1986). Hāfiz and His Contemporaries. In P. Jackson, \& L. Lockhart (Eds.), The Cambridge History of Iran: The Timurid and Safavid Periods (pp. 929-947). Cambridge: Cambridge University Press.

Schimmel, A. (1992). A Two-Colored Brocade: The Imagery of Persian Poetry. Chapel Hil: University of North Carolina Press.

Shayegan, D. (1985). The Visionary Topography of Hafiz. A Review Devoted to the Arts of Imagination (pp. 207-286).

Simidchieva, M. (2003). Imitation and Innovation in Timurid Poetics: Kāshifí’ s Badāya' al-afkār and Its Predecessors, al-Mu'jam and Ḥadāiq al-siḥr. Iranian Studies, 6(4), 509-530. 
Solati, B. (2013). The Reception of Hafiz. Leiden: Leiden University Press.

Subtelny, M. E. (2011). Kāšefi, Kamāl-al-Din Hosayn Wã eż. Encyclopaedia Iranica.

Sultan Burhān al-Dīn's Sufi Correspondence. (1989). für die Kunde des Morgenlandes, 73, 33-45.

Ta birī bar ta birāt-i Ḥāfiz. (1988). Iran Nameh, 6(4), 574-596.

Tetley, G. E. (2009). The Ghaznavid and Seljuk Turks: Poetry as a Source for Iranian History. London: Routledge.

Thackston, W. M. (1994). A Millennium of Classical Persian Poetry: A Guide to the Reading and Understanding of Persian Poetry from the Tenth to the Twentieth Century. Bethesda, MD: Iran Books.

The Development of Iranian Literature (E. Yarshater, Ed.). (1988). New York: Bibliotheca Persica/Persian Heritage Foundation.

The Rise and Rule of Tamerlane. (1989). Cambridge: Cambridge University Press.

The Sufi Doctrine of Rumi: An Introduction. (1974). Tehran: Aryamehr University Press.

The Sufi Path of Knowledge: Ibn al- 'Arabi’s Metaphysics of Imagination. (1989). New York: New York University Press.

The Sufi Path of Knowledge: Ibn 'Arabì's Metaphysics of Imagination. (1989). Albany: Suny Press.

The Sufi Path of Love: The Spiritual Teachings of Rumi. (1989). Albany: Suny Press.

Welcoming Fighānī: Imitation and Poetic Individuality in the Safavìd-Mughal Ghazal. (1998). Costa Mesa, CA.

Yarshater, E. (1986). Persian Poetry in the Timurid and Safavid Periods. In P. Jackson (Ed.), The Cambridge History of Iran (pp. 965-994). Cambridge: Cambridge University Press.

Zakeri, M. (1993). Sāsānid Soldiers in Early Muslim Society: The Origins of 'Ayyārān and Futuwwa. Includes bibliographical references and indexes. University of Utah.

Zipoli, R. (1988). Encoding and Decoding Neopersian Poetry. Rome.

\section{Notes}

Note 1. Davis, Vais u Rāmin. Vais u Rāmin is an eleventh-century verse romance by Fakhr al-Din Asad Gurgānī, a poet about whom virtually nothing is known. However, the importance of Vais u Rāmin as an aesthetic artifact in its own right, as a witness to Persian pre-Islamic mores and literary production, and as the inspirational Persian verse romance, has secured Gurgānī’s position, along with Ferdowsi, as one of the two most noteworthy Persian narrative poets of the eleventh century.

Note 2. Tafwif, in poetic terms, is generally considered as simplicity in writing. A poem (or part of a poem) composed in such a style and manner is easy to read and relatively simple to comprehend, with each verse logically connected to the preceding and following lines. In addition, such a poem rhymes correctly and consistently.

Note 3. Aporia is a figure of speech wherein a speaker claims to be in doubt or perplexity regarding a question (often feigned) and asks the audience how he or she ought to proceed. The doubts may appear 
as rhetorical questions, often in the beginning of the text. Aporia is a logical paradox in which the speaker sows seeds of doubts in a subject. This rhetorical strategy seeks to make the audience feel sympathy for the speaker's dilemma.

Note 4. Mas 'ūd-i Sa 'd-i Salmān (d. 515/1121-2) was a Persian court poet and royal librarian of the later Ghaznavid period. His divān (collected poems) contains many references-including poems in the form of fath-nāmas (books of victories) — to the conquests of Indian cities such as Kannauj, Narain (Narayanpur, Rajasthan), and Agra and has been an important source for the history of the later Ghaznavid in India. He was born in Lāhūr (in Punjab) and probably died in Ghazna (in present-day Afghanistan). The details of his life are only vaguely known.

Note 5. Abu Ali Hasan ibn Ali Ṭūsī (420/1018-494/1092), otherwise known as Nizāam al-Mulk (Order of the Realm), was a Persian scholar and court minister of the Saljuq Empire. He held absolute power for twenty years after the assassination of Alp Arsalān in 474/1072.

Note 6. Marmura, "Ḡazālī and Theology". "Ḡazālī argued that the main role of kalām is the preservation (hefž) and guardianship (ḥerāsa) of true religious belief ('aqīda), that is, traditional belief guided by the customary practice (sonna) of the Prophet. Kalām's task is corrective: to correct distortions in the exposition of belief by the heretical innovators (ahl-al-beda'). It is intended to persuade the few, those sincere doubters who are intellectually capable of following its arguments. For this persuasive reason, each region should have a theologian (motakallem). The commonality, however, must not be exposed to kalām. For Gazālī, kalām is not an end in itself. It is an error, he maintains, to think that practicing the discipline of kalām constitutes what is experientially religious". Cf. Lewis, Rumi Past and Present, East and West, 23.

Note 7. "Nothing is known of his life. Allusions in his poetry indicate that he was a professional poet and had suffered reverses; in one distich (Āfarīn-nāma, line 36; in Lazard, Premiers poètes) he presents himself as a stranger imploring the protection of the 'king of the world,' probably the Samanid amir". Lazard, "Abu Sakur Balki”.

Note 8. 'Arif is defined as an individual who has reached the state of enlightenment; his knowledge and wisdom are obtained through his vision, his utmost desire being union with the divine. Nürbakhsh, Farhang-i Nūrbakhsh, 3:260, s.v. "Ārif".

Note 9. For further understanding of the above statement, refer to translations of the Divan by Wilberforce Clarke, Meher Baba, Rajā' '⿳亠丷厂, and others.

Note 10. For further study of Sa 'dī's narratives, refer to Kulliyāt-Sa 'di; ed. Muhammad 'Alī Furūghī. 